\title{
"Inflation and economic growth: the search for a compromise for the Central Bank's monetary policy"
}

\author{
Volodymyr Mishchenko iD https://orcid.org/0000-0002-8565-2686 \\ R http://www.researcherid.com/rid/N-4143-2018 \\ Svitlana Naumenkova (D https://orcid.org/0000-0001-8582-6044 \\ AUTHORS \\ R https://publons.com/researcher/2083490/svitlana-naumenkova/ \\ Svitlana Mishchenko iD https://orcid.org/0000-0002-1840-8579 \\ R https://publons.com/researcher/1895078/svitlana-v-mishchenko/ \\ Viktor Ivanov iD https://orcid.org/0000-0003-4121-0605 \\ R http://www.researcherid.com/rid/K-9180-2015
}

Volodymyr Mishchenko, Svitlana Naumenkova, Svitlana Mishchenko and Viktor $\begin{array}{ll}\text { ARTICLE INFO } & \text { Ivanov (2018). Inflation and economic growth: the search for a compromise for the } \\ \text { Central Bank's monetary policy. Banks and Bank Systems, 13(2), 153-163. doi: }\end{array}$ $10.21511 / \mathrm{bbs} .13(2) .2018 .13$

DOI http://dx.doi.org/10.21511/bbs.13(2).2018.13

RELEASED ON Thursday, 05 July 2018

RECEIVED ON Monday, 07 May 2018

ACCEPTED ON

Wednesday, 27 June 2018

\section{(cc) EY-NC}

LICENSE

This work is licensed under a Creative Commons Attribution-NonCommercial 4.0 International License

JOURNAL

"Banks and Bank Systems"

ISSN PRINT

1816-7403

ISSN ONLINE

$1991-7074$

PUBLISHER

LLC "Consulting Publishing Company "Business Perspectives"

FOUNDER

LLC "Consulting Publishing Company "Business Perspectives"

NUMBER OF REFERENCES

29
NUMBER OF FIGURES

3
NUMBER OF TABLES

2

(C) The author(s) 2022. This publication is an open access article. 


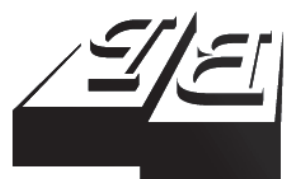

BUSINESS PERSPECTIVES

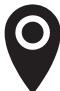

LLC "CPC "Business Perspectives" Hryhorii Skovoroda lane, 10, Sumy, 40022, Ukraine

www.businessperspectives.org

Received on: $7^{\text {th }}$ of May, 2018 Accepted on: $27^{\text {th }}$ of June, 2018

(C) Volodymyr Mishchenko, Svitlana Naumenkova, Svitlana Mishchenko, Viktor Ivanov, 2018

Volodymyr Mishchenko, Doctor of Economics, Professor, Department of Economics and Management, University of Banking, Ukraine

Svitlana Naumenkova, Doctor of Economics, Professor, Department of Finance, Taras Shevchenko National University of Kyiv, Ukraine

Svitlana Mishchenko, Doctor of Economics, Associate Professor Department of Finance, Banking and Insurance, University of Banking, Ukraine

Viktor Ivanov, Doctor of Economics, Professor, Department of Credit Theory and Financial Management, Saint Petersburg State University, Russian Federation

\section{(ㄷ)(1) (8)}

This is an Open Access article, distributed under the terms of the Creative Commons Attribution-NonCommercial 4.0 International license, which permits re-use, distribution, and reproduction, provided the materials aren't used for commercial purposes and the original work is properly cited.
Volodymyr Mishchenko (Ukraine), Svitlana Naumenkova (Ukraine), Svitlana Mishchenko (Ukraine), Viktor Ivanov (Russian Federation)

\section{INFLATION AND ECONOMIC GROWTH: THE SEARCH FOR A COMPROMISE FOR THE CENTRAL BANK'S MONETARY POLICY}

\section{Abstract}

The article analyzes the influence of inflation on economic growth and substantiates the main directions of increasing the effectiveness of central bank anti-inflation policy.

In order to determine the threshold of inflation, the excess of which has a negative impact on the economic growth, the relationship is analyzed between the inflation rate and the real GDP growth rate on the basis of IMF statistics using the example of 158 countries. It was determined that in 2010-2017, in the global economy, the $6.0 \%$ inflation was the marginal value of the inflation rate, beyond which the economic growth rate declined or slowed down.

Given the inverse relationship between the inflation rate and the real GDP growth rates as well as empirical calculations for the period 1996-2017, the threshold for inflation rate for Ukraine at the level of $4.51 \%$ was determined based on empirical calculations for the 1996-2017 period. The results indicate that the National Bank of Ukraine set the inflation target above the level of the calculated threshold inflation.

It has also been established that the link between the rates of nominal GDP growth, as opposed to real GDP, and the inflation rate, is more direct and tighter. It is substantiated that in order to analyze such dependence it is necessary to use GDP deflator instead of CPI. The results indicate that deflation constrains economic growth much less than inflation.

In order to increase the effectiveness of central bank pro-cyclical monetary policy aimed at supporting economic growth, the correlation between the rates of real GDP growth and the indicator characterizing the gap between the growth rates of M3 and inflation, which actually reflects the real money supply dynamics, is determined. The results obtained allowed to conclude that in 2009 and 2014-2017, the artificial "squeezing" of the money supply took place in Ukraine, resulting in a decrease in the level of the economy monetization by $22.0 \%$ in 2017 compared to 2013 .

It has been proved that in order to minimize the negative impact of inflationary processes on economic growth, the policy of the National Bank of Ukraine should be aimed at eliminating the artificial "squeezing" of the money supply through a reasonable increase in the economy monetization and the implementation of an effective monetary policy.

\section{Keywords} monetary policy, central bank, inflation, GDP, money supply, economic growth, monetary regulation

\section{JEL Classification E31, E52, E58}

\section{INTRODUCTION}

Due to the need to ensure a high and stable rate of economic growth, as well as the development and implementation of an effective anti-inflation policy, the search for the relationship between inflation and economic growth remains relevant for central banks and governments in many countries of the world.

The study of this relationship has been made actual since the 1980s, when, after the practical implementation of the main monetarism provisions in the central banks activity, scientists and practitioners faced 
a sharp rise in inflation, which at that time was mainly due to monetary factors. Today, due to the introduction of inflation targeting mechanisms in most countries, inflation remains at a low and controlled level, but for central banks and governments in developing countries, the issue of developing an effective anti-inflation policy is relevant.

Over the past decades, there has been a slowdown in economic growth and uneven economic development in the world. In some countries there are recessions or declines in production due to financial and banking crises that result from the imbalance of natural and costly flows, as well as economic and political instability. Ultimately, such financial instability provokes an increase in inflationary processes.

Special role in balancing monetary flows and economic growth rates belongs to central banks, which, as a rule, reluctantly participate in the processes of stimulating economic development. Central banks limit their functions to purely operational approaches to forecasting interest rates and monetary indicators, neglecting the developing and implementing a pro-cyclical monetary policy aimed at supporting economic growth (Mishchenko, Naumenkova, \& Lon, 2016). In addition, developing countries often lack the proper coordination of monetary and fiscal policies, which also hold back economic growth.

Inflation is an extremely complex economic phenomenon, which requires a thorough study and analysis, including the channels for the transfer of inflationary impulses to the real economy. Most studies have noted the negative effects of inflation on economic growth after reaching a certain threshold. However, the definition of such a level is based mainly on the use of a purely instrumental approach. Researchers do not pay enough attention to the effective anti-inflationary policies by governments and central banks, and high inflation rates are sometimes viewed as one of the characteristics of a weak economy with weak institutions (Khan \& Senhadji, 2001).

In particular, it concerns channels to form money supply in circulation, the import of inflation, administrative influence by setting prices for certain goods and services or through the level of public expenditures, etc. A high level of inflation may not only be a deterrent to economic growth but also a source of political and systemic threats to world financial markets (Espinoza, Leon, \& Prasad, 2010).

In world practice, a significant number of examples have been accumulated that characterize different options for the ratio of economic growth and inflation. Economic growth is also possible under high inflation, or, conversely, in case of deflation. For example, in Ukraine during 1992-2017, deflation was observed twice, in $2002(-0.6 \%)$ and in $2012(-0.2 \%)$, while the real GDP growth rates were $5.2 \%$ and $0.2 \%$, respectively, in these years.

Given that the main task of the macroeconomic policy of governments and central banks is to provide and maintain stable economic growth, high employment and low inflation, the purpose of the current study is to determine the nature and extent of the impact of inflation on economic growth, using the example of a small open economy, and to substantiate the directions of increasing the effectiveness of anti-inflationary policy in Ukraine.

\section{LITERATURE REVIEW}

In the scientific literature, the issue of establishing quantitative interconnections between key macroeconomic indicators, in particular, between inflation and economic growth, has traditionally been given a great deal of attention. The theoretical basis for these studies is the work of monetarists and, above all, Friedman and Schwartz (1970), who developed the foundations of a non-monetary theory, according to which the central bank's policy on the money supply management should play a key role in stimulating economic development.

Continuing this tradition, Orphanides and Solow (1990) analyzed the effect of the money supply on the 
main macroeconomic indicators and determined the relationship between the inflation rate and the GDP dynamics, which later formed the basis for the Orphanides rule, based on using not the absolute values of the studied indicators, but their trend.

Based on the analysis of the Fischer equation of exchange, Blinov concluded that economic growth depends on the ratio of the growth rates of money supply and the growth rates of prices (Blinov, 2017). However, such an approach ignores the issue of selecting monetary transmission channels to increase money supply in circulation, which is an important practical issue for central banks.

In general, in the scientific literature, an empirically confirmed point of view prevails that a high level of inflation negatively affects economic growth. However, the question remains regarding the definition of the marginal level of inflation (for developed and non-developed countries), whose excess is negatively affecting economic growth and requires correction of the anti-inflation policy of the government and the central bank.

Espinoza, Leon, and Prasad (2010), using the smooth transition model and taking calculations for 165 countries in the period 1960-2007 into account, stated that developed countries have a threshold value of inflation of $1 \%$, and for countries with emerging markets, an inflation barrier for economic growth may be $10 \%$ or more.

Kremer, Bick, and Nautz (2013), using the dynamic panel threshold model in the context of 124 countries of the world for 1950-2004, calculated that for industrially developed countries the threshold value of inflation is equal to $2 \%$, and for countries that are not industrially developed it exceeds $17 \%$. According to researchers, if in developing countries inflation is less than $17 \%$, then this is not a significant obstacle to their economic growth.

Eggoh and Muhammad (2014), based on data from 102 countries using the PSTR and dynamic GMM methods, concluded that the relationship between inflation and economic growth is non-linear and proposed several inflation thresholds for different samples. For developed countries, the threshold of inflation is set at $3 \%$, and for developing countries it is at $10-12 \%$. In addition, the authors identified certain indirect channels of inflation influence on economic growth and proved that inflationary tolerance in developing countries is significantly higher than in developed ones.

Ibara and Trupkin (2016), using the PSTR smooth transition model and the example of 124 countries in the period 1950-2007, calculated the thresholds for inflation, the excess of which adversely affects economic growth. The authors estimate the threshold for developing countries at the level of $19.1 \%$, and for developed countries at $4.1 \%$. In addition, according to the authors, in case of improvement of institutes' activities, the threshold value of inflation in developing countries can be reduced to $7.9 \%$.

Empirical studies by López-Villavicencio and Mignon (2011) for a sample of 42 countries allowed the inflation thresholds of $2.7 \%$ for developed countries and $17.5 \%$ for developing ones. Similar results were obtained by Omay and Kan (2010), whose calculations have shown that for industrially developed countries the threshold of inflation does not exceed $2.52 \%$. Barro found that rising inflation by $10 \mathrm{pp}$ led to a decline in the real GDP per capita growth rate by 0.2-0.3 pp. (Barro, 2013).

Other definitions of the threshold values of the inflation rate are found in the literature, for example: 8\% (Sarel, 1996); 3-6\% (Khan \& Senhadji, 2001); 9\% (Kartayev, 2017) and others, due to the use of different sample sizes, time periods, specification of selected models, the nature of inflation processes during the period under study, etc.

The research on the correlation between inflation and economic growth for closed and open economies deserves attention. According to Sachsida, Carneiro, and Loureiro (2003), in countries with open economies, the negative impact of inflation on economic growth is significantly enhanced after reaching the threshold. Pain, Koske, and Sollie (2006) have argued that increasing the level of the economy openness leads to the fact that prices for imported goods have a significant effect on prices in the domestic market.

Analysis of indirect channels of influence on inflation dynamics and economic growth is an important area of research. Ezirim, Muoghalu, and Elike 
(2008), using the USA as an example, have shown that an increase in public spending contributes to an increase in inflation. According to their findings, excessive government expenditures increase consumer demand and crowd out production investments. Such results are also confirmed by Han and Mulligan (2008)'s case studies of 80 countries.

Lioui and Poncet (2008), Gillman and Kejak (2011) investigate the effect of interest rate on inflation dynamics and conclude that high inflation inhibits long-term investments, reduces the productivity of all factors of production and, thus, reduces production in the future. Mendoza and Terrones (2008), based on a study of credit booms in 48 countries, found the dependence of the inflation rate on the increase in the balance of loan indebtedness.

Kartayev (2017), Leong, Puah, and Liew (2018), Zhuravka (2008) analyze the correlation of inflation and economic growth with the exchange rate dynamics and conclude that it is necessary to combine inflation targeting with the exchange rate targeting.

Malyovanyi, Nepochatenko and Nesterchuk (2018) estimated the influence of social expenditures and their structure on economic growth and inflation in the OECD countries for the period 1980-2015.

Since 2000s, the study of the influence of central banks' policy aimed at inflation targeting was a new direction in the study of inflation and economic growth. A number of researchers believe that the inflation targeting is most beneficial for emerging market countries, as it contributes to a controlled and substantial reduction in inflation (Lin \& Ye, 2007). However, most scholars are convinced that using inflation targeting can be beneficial both for developing and developed countries (Mollick, Cabral, \& Carneiro, 2011; Kurihara, 2013).

\section{DATA AND METHODS}

The study relies on the International Monetary Fund and the National Bank of Ukraine statistics, as well as on the authors' calculations based on the combination of economic and statistical methods of analysis.
In order to analyze the dynamics of GDP growth rate depending on the inflation rate, data for 2010 2017 are used according to the corresponding range of 158 countries, whose GDP is more than $0.005 \%$ of the global GDP. The grouping of countries by the inflation rate was conducted on the following scale: "not over 0.0 (deflation)", "from 0.0 to $2.0 \%$ ", "from 2.0 to $5.0 \%$ ", "from 5.0 to $8.0 \%$ ", and "over 8.0\%".

Countries with an unstable political and economic situation, as well as those where hostilities are being conducted, including Syria, Iran, Sudan, Libya, South Sudan and Venezuela, were not included in the statistical sample.

In order to analyze the studied interconnections in Ukraine, the period 1996-2017 was chosen, since before 1996, there was a galloping inflation accompanied by a constant decline in GDP, which makes it impossible to compare the results. To analyze the inflation rate, as in most studies, the consumer price index (CPI) has been used, and to characterize economic growth, the annual growth rates of real and nominal GDP were used, since it is precisely these indicators that are sufficiently complete and reliable statistics. In addition, they are the main macroeconomic indicators, which are approved in government forecasts.

During the establishing quantitative relationships between the investigated parameters, linear dependence was used on the basis of the correlation analysis and the pairwise regression equations. Analysis of possible variants of using nonlinear dependence based on the source data linearization did not allow obtaining statistically significant results, but, on the contrary, deteriorated them to a great degree.

While studying theoretical and methodological aspects of the relationship between inflation and economic growth, the monographic method, the methods of analysis and synthesis and the method of expert evaluations were used. In order to perform a comparative evaluation of the results, methods of analogy, grouping, sampling, averaging of data and analytical method were used. Methods of scientific abstraction and system-structural analysis were implemented in developing recommendations for improving the anti-inflationary policies of governments and central banks. 


\section{RESULTS}

The current stage of the world economy development is characterized by moderate economic growth under the moderate inflation. Over the last eight years, economic growth has slowed down in many G20 countries, including China, India and Russia. At the same time, the inflation rate, gradually slowing down, remained within the limits controlled by the central banks.

An analysis of the correlation between the inflation rate and the real GDP growth rate using the example of 158 countries in 2010-2017 made it possible to conclude that the increase in inflation significantly constrains the pace of economic growth. The calibration of countries by the inflation rate shows that most of them are in the second, third and fourth groups, that is, the range of fluctuations in the inflation rate is from 0 to $8 \%$. In 2015 , the share of countries belonging to these three groups was $69 \%$, and in 2017 it was $88 \%$, indicating significant fluctuations of the studied indicators both in time and in separate groups of countries.

Based on the analysis of the data obtained, it was concluded that among the 158 countries studied in 2010-2017, with an average inflation rate of $4.94 \%$, the real GDP growth rate was $3.37 \%$. At the same time, in the fifth group of countries where the inflation rate exceeded $8.0 \%$, annual growth rates of real GDP slowed down to $2.49 \%$ and show a clear tendency to further decrease. In addition, the results suggest that deflation inhibits the growth of real GDP to a much lesser extent than high inflation, since in the first group of countries the average weighted growth rate of real GDP was $2.58 \%$, while in the fifth group it was $2.49 \%$ (Table 1).

Table 1. Grouping the countries of the world based on the GDP growth rates dependence on the inflation rate in 2010-2017

Source: Calculated based on the IMF data http://www.imf.org

\begin{tabular}{|c|c|c|c|}
\hline $\begin{array}{l}\text { The scale of distribution } \\
\text { of countries by the inflation rate, } \\
\%\end{array}$ & $\begin{array}{l}\text { Average number of } \\
\text { countries in the group }\end{array}$ & $\begin{array}{l}\text { Average weighted } \\
\text { inflation rate, } \%\end{array}$ & $\begin{array}{c}\text { Average weighted value } \\
\text { of the real GDP growth } \\
\text { rate, \% }\end{array}$ \\
\hline 1. Not exceeding 0 (deflation) & 9 & -0.51 & 2.58 \\
\hline 2. From 0.0 to 2.0 & 37 & 1.15 & 2.78 \\
\hline 3. From 2.0 to 5.0 & 54 & 3.01 & 3.81 \\
\hline 4. From 5.0 to 8.0 & 31 & 6.03 & 4.31 \\
\hline 5. Above 8.0 & 27 & 14.58 & 2.49 \\
\hline Total & 158 & 4.94 & 3.37 \\
\hline
\end{tabular}

Source: Developed by the authors.

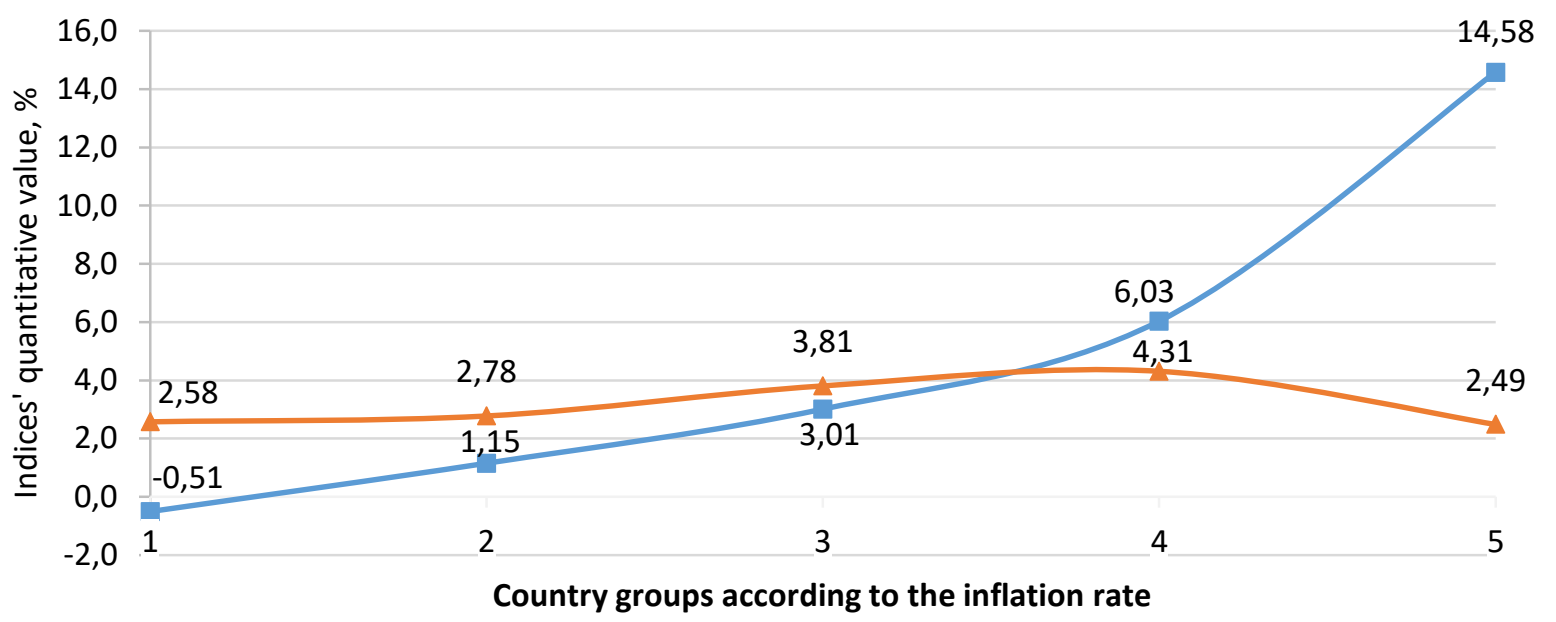

- Mean value of the inflation rate for the corresponding group, \%

- Mean value of the real GDP growth rate, \%

Figure 1. Graphic presentation of real GDP growth rate dependence on inflation in 158 countries of the world in 2010-2017 
The analysis also provides grounds for arguing that in 2010-2017, in the world economy the inflation rate at the level of $6.0 \%$ (Figure 1) was the limit value of inflation, beyond which the economic growth rates declined or substantially slowed down (Figure 1), which generally is consistent with the results of research by other scholars.

As the analysis shows, in the scientific literature, as a statistical sample, long time intervals are used, although, in the authors' opinion, this is not always justified from a practical point of view. For example, some studies covered the period from the 1950s to the present (Ibarra \& Trupkin, 2016; Kremer, Bick, \& Nautz, 2013). However, it should be borne in mind that in the 1950s-1960s, during the world economy recovery, demand inflation dominated, and in the 1970s - expense inflation that was due to the energy crisis and rising prices for energy resources. In the 1980s, the main influence on inflationary processes was caused by monetary factors associated with the significant expansion of financial markets and the introduction of monetary methods for the economy regulation by the central banks based on the expansion of the money supply in circulation. In the 1990s and 2000s, inflation was mainly due to financial and banking crises, the devaluation of many national currencies, and other factors. The 2010 inflationary processes were mainly influenced by the consequences of the 2008-2009 global financial crisis, budget crises, tariff wars, the imposition of sanctions, etc., which generally hampered economic growth.

In the authors' opinion, long-run studies, along with the benefits, have certain disadvantages associated with the fact that long-term trends offset the influence of specific factors and do not allow identifying the features of inflationary processes in each particular period. During this time, many parameters and characteristics change, and the nature of the inflation itself changes too. For practical purposes, prediction of macroeconomic indicators and the development of anti-inflationary policies not only require historical data, but also actual data characterizing current trends. Therefore, in the authors' view, to forecast macroeconomic indicators, the analysis of data for 8-10 years will be enough.

Some studies provide recommendations for using quarterly data (Barro, 2013), which is generally sound. For example, during 2008-2017 in
Ukraine, three years saw a decline in production (2009, 2014-2015), and two years (2012-2013) witnessed a recession. It is clear that in such a situation, for the purposes of forecasting, data will be more reliable for a relatively short historical period, but by quarters. Using quarterly data provides more operational information and opportunities for forecasting, and allows for a wide range of specific factors to be taken into account.

An analysis of inflationary processes and their impact on economic growth in Ukraine suggests that during 1991-1995, hyperinflation was observed in the country. Thus, in 1992 , inflation was $2100 \%$, and in $1993-10356 \%$. However, already in 1995, inflation slowed down to $287.1 \%$ and since 1996 it began to decline gradually. For the period 1996-2017, the average annual inflation rate was $14.64 \%$, while the average growth rate of real GDP was only $1.36 \%$.

In order to study the influence of inflation processes on the real GDP dynamics in Ukraine in 1996-2017 and to establish quantitative relationships between the parameters investigated, linear dependence was used based on the construction of the pair regression equation. As a result of calculations, the following equation is obtained:

$$
y=-0.3108 x+5.9111
$$

where $y$ - the real GDP growth rate, $\% ; x$ inflation rate, $\%$

An analysis of the results shows that there was an inverse relationship between the inflation rate and the rates of real GDP growth in 1996-2017: with an increase in inflation rate by $1 \%$, the growth rate of real GDP decreased by $0.3108 \%$.

The estimation of the parameters of the obtained equation by the least squares method indicates its statistical significance. The tightness of the relationship between the selected factors, which is determined by the correlation ratio, was: $r=-0.5132$. This value of $r$ indicates that, on the Cheddock scale, the level of relationship between the selected indicators is "noticeable". The determination coefficient $(R 2)$ for the calculated model was 0.2633 , that is, in $26.33 \%$ of cases, the change in the inflation rate leads to changes in the rates of real GDP growth. 
The actual value of Student's $t$-criterion was 2.6740, and the tabular one was 2.086 , which is confirmed by the inequality $t>t_{k r}$ and the statistical significance of the correlation coefficient. The verification of the statistical significance of the equation using Fisher's criterion showed that the tabular value of this indicator was 4.35 , and the actual value was 7.149 , that is, $F>F_{k r}$. The coefficient of elasticity was 3.349, exceeding 1 .

The analysis of the chart constructed on the basis of equation (1) shows that the empirical lines of inflation rate and the growth rates of real GDP are crossed at point 4.51 (Figure 2). Therefore, it can be assumed that the threshold value of inflation in Ukraine in 1996-2017 was an indicator at 4.51\%. However, since the average inflation rate over the analyzed period exceeded the threshold, it kept constraining the growth rate of real GDP.

Given the results obtained, it can be concluded that the inflation target set in 2016 by the National Bank of Ukraine at the level of $5+1 \%$ exceeds the estimated value.

In order to clarify the revealed bonds, an equation of pair linear regression was constructed which characterizes the effect of the change in the inflation rate on the nominal GDP dynamics in Ukraine in 1996-2017. As a result of calculations, the following equation was obtained:

$$
y=11.7511+0.6107 x,
$$

where $y$ - nominal GDP growth rate, $\% ; x$ inflation rate, $\%$.

The results obtained indicate that the connection between the selected indicators is straight and is characterized as "noticeable" according to the Chaddock scale. The analysis of the obtained equation shows that the $1 \mathrm{pp}$ increase in the inflation rate is accompanied by a $0.6107 \%$ increase in nominal GDP.

The tightness of the connection between the selected factors in the model (2) was higher: $r=0.5722$, and $R 2=0.3271$. Calculated values of the elasticity coefficient, Student's criterion and Fischer's criterion indicate the significance of the results obtained.

However, from a methodological point of view, the comparison of the growth rate of nominal GDP with the inflation rate, determined on the CPI basis, is incorrect. According to the authors, in order to assess the impact of inflationary processes on the economic growth on the basis of the nominal GDP dynamics, it is expedient to use the GDP deflator index, which includes the indices of price changes for all goods produced per year in the country, and not only those included in the CPI calculation.

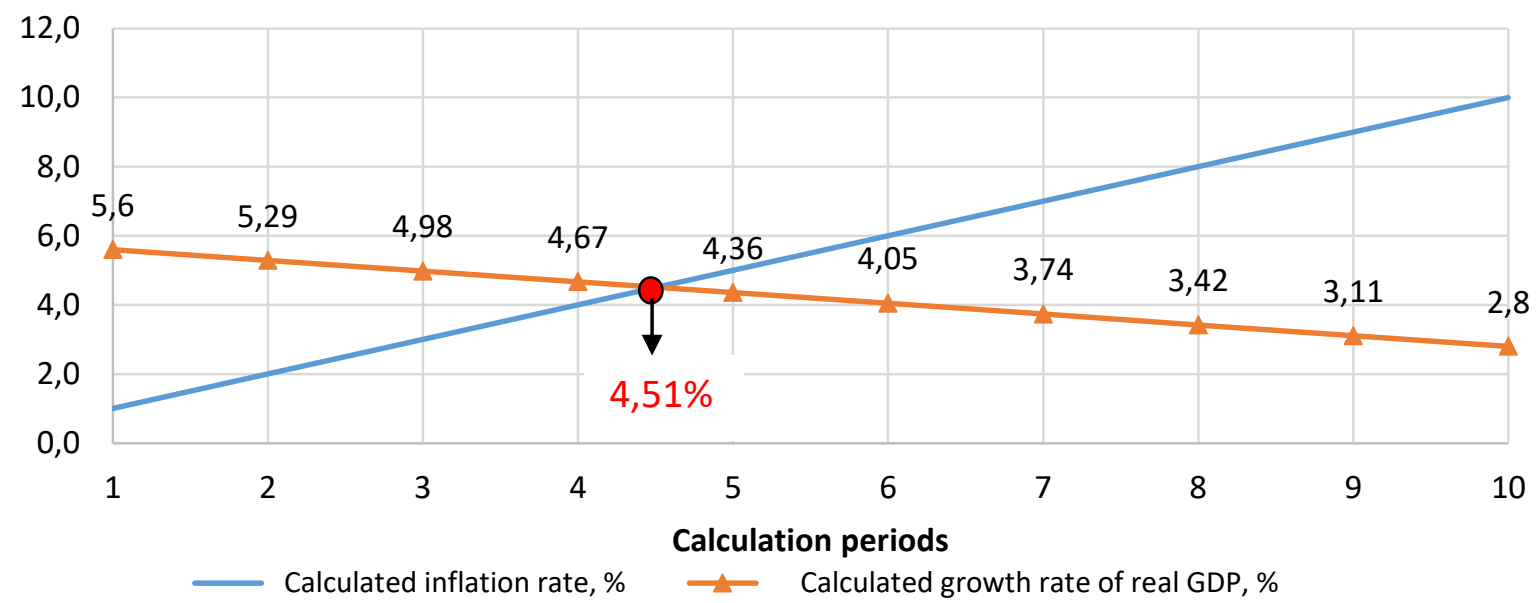

Figure 2. The empirical dependence of the real GDP growth rate on the inflation rate in Ukraine according to the regression equation (1) 
The calculations carried out using the Ukraine's data for 1996-2017 indicate a high degree of direct influence of the GDP deflator dynamics on the growth rates of nominal GDP. The following empirical linear regression equation is obtained:

$$
y=0.7399 x+6.4889
$$

where $y$ - nominal GDP growth rate, $\% ; x-$ GDP deflator rate, $\%$.

The economic interpretation of the results shows that in the period under study the $1 \mathrm{pp}$ increase of the GDP deflator contributed to the nominal GDP growth by $0.7399 \mathrm{pp}$.

The high value of the correlation coefficient $(r=0.8082)$, the determination coefficient $(R 2=0.6530)$, the $t$-statistic and $F$-statistics indicate the statistical significance of the results obtained. The obtained estimates of the regression equation allow us to use it for forecasting.
The fact that, according to equation (3), in $65.3 \%$ of cases the change in the GDP deflator leads to a change in the nominal GDP growth rate can be interpreted as an evidence of the inflationary nature of the modern economy development.

This conclusion is confirmed by the analysis of the statistical data (see Table 2). Over the analyzed period, inflation in Ukraine was accompanied by high growth rates of the M3 monetary aggregate, however, the link between the growth rates of M3 and the inflation rate was very weak. More significant was the relationship between the real GDP growth rates and the gap between the growth rates of M3 and the inflation rate. According to the methodology proposed by Blinov (2017), this indicator actually characterizes the dynamics of the real money supply.

In order to determine the quantitative relationships between these indicators, the following regression equation was constructed:

Table 2. Dynamics of the main macroeconomic and monetary indicators in Ukraine in 1996-2017

Source: Calculated by the authors based on the NBU data.

\begin{tabular}{|c|c|c|c|c|c|c|}
\hline Year & $\begin{array}{l}\text { Inflation rate } \\
\text { (CPI), \% }\end{array}$ & $\begin{array}{l}\text { M3 growth } \\
\text { rate, \% }\end{array}$ & $\begin{array}{c}\text { Average } \\
\text { weighted } \\
\text { discount rate, } \\
\%\end{array}$ & $\begin{array}{l}\text { Real GDP } \\
\text { growth rate, } \%\end{array}$ & $\underset{\%}{\text { GDP deflator, }}$ & $\begin{array}{l}\text { Nominal GDP } \\
\text { growth rate, \% }\end{array}$ \\
\hline 1996 & 139.7 & 135.1 & 62.3 & 90.0 & 166.2 & 154.1 \\
\hline 1997 & 110.1 & 134.0 & 24.6 & 97.0 & 118.1 & 114.6 \\
\hline 1998 & 120.0 & 125,3 & 61.6 & 98,1 & 112.1 & 109.9 \\
\hline 1999 & 119.2 & 140.8 & 50.0 & 99.8 & 127.3 & 127.1 \\
\hline 2000 & 125.8 & 145.2 & 30.6 & 105.9 & 123.1 & 130.4 \\
\hline 2001 & 106.1 & 142.1 & 19.7 & 109.2 & 109.9 & 120.0 \\
\hline 2002 & 99.4 & 142.8 & 9.5 & 105.2 & 105.1 & 110.6 \\
\hline 2003 & 108.2 & 146.4 & 7.0 & 109.6 & 108.0 & 118,4 \\
\hline 2004 & 112.3 & 131.9 & 7.5 & 112.1 & 115.1 & 129.1 \\
\hline 2005 & 110.3 & 154.4 & 9,2 & 102.7 & 124.5 & 127,9 \\
\hline 2006 & 111.6 & 134.5 & 9.0 & 107.3 & 114.8 & 123.2 \\
\hline 2007 & 116.6 & 151.7 & 8.0 & 107.9 & 122.7 & 132.5 \\
\hline 2008 & 122.3 & 130.2 & 11.3 & 102.3 & 128.6 & 131.6 \\
\hline 2009 & 112.3 & 94.5 & 11.3 & 85.5 & 113.0 & 96.3 \\
\hline 2010 & 109.1 & 122.7 & 9.1 & 104.1 & 115.4 & 118.5 \\
\hline 2011 & 104.6 & 114.7 & 7.8 & 105.5 & 114.2 & 120.3 \\
\hline 2012 & 99.8 & 112.8 & 7.6 & 100.2 & 108.0 & 108.4 \\
\hline 2013 & 100.5 & 117.6 & 7.1 & 100.0 & 104.3 & 103.1 \\
\hline 2014 & 124.9 & 105.2 & 10.2 & 93.2 & 114.8 & 109.1 \\
\hline 2015 & 143.3 & 103.9 & 26.1 & 89.5 & 138.4 & 125.3 \\
\hline 2016 & 112.4 & 110.9 & 17.5 & 102.3 & 117.1 & 119.8 \\
\hline 2017 & 113.7 & 107.3 & 13.1 & 102.5 & 122.0 & 125.2 \\
\hline
\end{tabular}




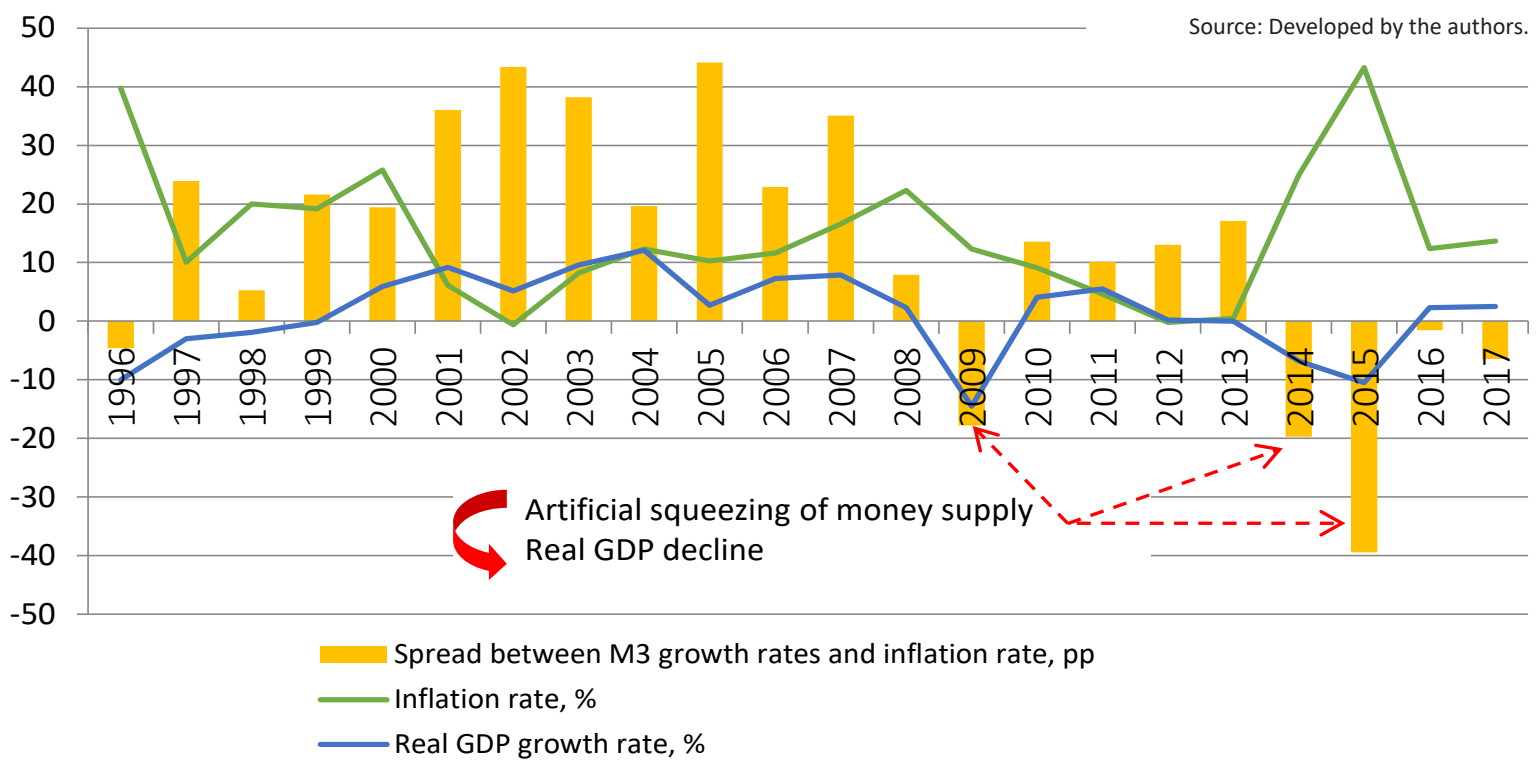

Figure 3. Dynamics of the inflation rate, real GDP growth rate and the spread between the M3 growth rates and inflation rate in Ukraine in 1996-2017

$$
y=0.2269 x-1.1951,
$$

where $y$ - real GDP growth rate; $x$ - difference (spread) between $M 3$ growth rates and the inflation rate, pp.

The obtained results indicate that the increase in the spread between the growth rates of the monetary aggregate $\mathrm{M} 3$ and the inflation rate by $1 \mathrm{pp}$ for the period of 1996-2017 contributed to an increase in the real GDP growth rate by $0.2269 \mathrm{pp}$.

As a result of the calculations, it turned out that the degree of connection between these indicators according to the Chaddock scale is high $(r=0.7422$, $R 2=0.5513)$. The value of the elasticity coefficient is 1.69 , which means that an increase in the gap between the $M 3$ growth rates and the inflation rate substantially affects the real GDP growth rates. Student's criterion: $t_{k r}=2.093 ; t=4.832$, that is $t_{k r}<t$. Fischer's criterion: $F_{k r}=4.38$, and $F=23.34$, that is, $F_{k r}<F$, which indicates the high significance of the results obtained.

According to the study results, the difference between the M3 growth rates and the inflation rate was negative only in 1996, 2009 and in 2014-2017, which can be characterized as a process of artificial "squeezing" of the money supply by the central bank (see Table 2). This is also confirmed by the data on the rapid drop in the level of economy monetization, which in 2013 amounted to $62.5 \%$, and in 2017 it decreased to $40.5 \%$.

Figure 3 clearly demonstrates the correlation between the dynamics of inflation rates, the growth rates of real GDP and the gap between the growth rates of M3 and the inflation rate in Ukraine in 1996-2017. A significant slowdown in the growth rate of the M3 monetary aggregate in 2009 and 2014-2015 in comparison with the inflation rate due to the ill-conceived monetary policy of the central bank led to a decrease in the economic growth rates.

In order to minimize the negative impact of inflationary processes on Ukraine's economic growth, the policy of the National Bank of Ukraine should be aimed at eliminating the artificial "squeezing" of the money supply through a reasonable increase in the level of economy monetization and the implementation of an effective monetary policy. The main directions of increasing the level of the economy monetization should be the expansion of lending to the economy and strengthening the channels of the monetary transmission mechanism controlled by the central bank. In addition, the role of monetary policy of the central bank in stimulating economic growth should be to create certain monetary conditions, the main among them are macroeconomic stability, stability of the banking system and money circulation, as well as low and stable inflation. 


\section{CONCLUSION}

The analysis of the linkage between the inflation rate and the growth rate of real GDP on the basis of IMF statistics using the example of 158 countries of the world confirmed the negative impact of inflation on economic growth. Given the calculations, it was determined that in 2010-2017, in the global economy, the threshold inflation rate, beyond which the rate of economic growth declined or slowed down, was $6.0 \%$. The obtained results also showed that in world practice, deflation inhibits economic growth much less than high inflation.

The analysis of the statistical sample volumes made it possible to determine that long-term research, along with its advantages, also has drawbacks, and therefore, the use of quarterly data, which is more reliable and informative, is proposed for forecasting macroeconomic indicators and developing anti-inflationary policy measures.

Empirical calculations allowed determining the inverse effect of inflationary processes on economic growth in Ukraine, namely: in 1996-2017, with an increase in inflation rate by $1 \mathrm{pp}$, the growth rate of real GDP decreased by $0.3108 \mathrm{pp}$. An indicator of $4.51 \%$ is the threshold inflation rate for Ukraine. Exceeding this limit value of the inflation rate led to a systematic decrease in the growth rate of real GDP. Therefore, one can assume that the $5+1 \%$ inflation target set by the National Bank of Ukraine in 2016 exceeds the estimated value.

It was established during the study that the relationship between the rates of nominal GDP growth, in contrast to real GDP, and the inflation rate, is more direct and tighter. In 1996-2017, the increase of inflation by $1 \mathrm{pp}$ contributed to the growth of nominal GDP by $0.6107 \mathrm{pp}$. It was proved that in order to analyze such dependence it is better to use GDP rather than CPI.

The study made it possible to hypothesize that the peculiarity of the current stage of the world economy development is in its inflationary nature. For Ukraine, this is confirmed by calculations of the relationship between the real GDP growth rates and an indicator characterizing the gap between the growth rates of M3 and the inflation rate, which actually reflects the dynamics of the real money supply. The obtained results showed that an increase in the gap between the growth rates of the monetary aggregate $\mathrm{M} 3$ and the inflation rate by $1 \mathrm{pp}$ during the period under study contributed to an increase in the real GDP growth rate by $0.2269 \mathrm{pp}$.

The calculations show that in 2009 and 2014-2017, the process of artificial "squeezing" of the money supply took place in Ukraine, resulting in a decrease in the economy monetization by $22.0 \%$ in 2017 compared to 2013.

It is proved that in order to smooth out the negative impact of inflationary processes on the economic growth, the policy of the National Bank of Ukraine should be aimed at eliminating the artificial "squeezing" of the money supply through a reasonable increase in the level of the economy monetization and the implementation of the effective monetary policy. The main directions of increasing the level of the economy monetization should be the expansion of loans and strengthening the monetary transmission mechanism channels.

For emerging markets countries, promising areas of research may include identifying the links between inflation and financial dollarization, between inflation and unemployment, and determining the impact of the national currency devaluation and the state budget deficit on inflationary processes. 


\section{REFERENCES}

1. Barro, Robert J. (2013). Inflation and Economic Growth. Annals of Economics and Finance, 14(1), 85-109.

2. Blinov, S. (2017). Инфляция и экономический рост [Infliatsiya $i$ ekonomicheskiy rost] (MPRA Paper No. 78087). Retrieved from https:// mpra.ub.uni-muenchen.de/78087/

3. Bruno, M., \& Easterly, W. (1998). Inflation Crisis and Long-run Growth. Journal of Monetary Economics, 41(1), 3-26.

4. Eggoh, J. C., \& Muhammad, K. (2014). On the nonlinear relationship between inflation and economic growth. Research in Economics, Elsevier, 68(2), 133-143.

5. Espinoza, R., Leon, H., \& Prasad, A. (2010). Estimating the InflationGrowth Nexus - A Smooth Transition Model (IMF Working Paper No. 10-76). Retrieved from http://www. imf.org/external/pubs/ft/wp/2010/ wp1076.pdf

6. Ezirim, C. B., Muoghalu, M. I., \& Elike, U. (2008). Inflation versus Public Expenditure Growth in the U.S: An Empirical Investigation. North American Journal of Finance and Banking Research, 2(2), 26-40.

7. Friedman, M., \& Schwartz, A. (1970). Monetary Statistics of the United States. New York.

8. Gillman, M., \& Kejak, M. (2011). Inflation, Investment and Growth: A Money and Banking Approach. Economica, London School of Economics and Political Science, 78(310), 260-282. http://dx.doi.org/10.1111/ j.1468-0335.2009.00814.x

9. Han, S., \& Mulligan, C. B. (2008). Inflation and the size of the Government. Federal Reserve Bank of St. Louis Review, 90(3), 245-67.

10. Hineline, D. R. (2007). Examining the Robustness of the Inflation and the Growth Relationship. Southern Economic Journal, 73(4), 1020-1037.

11. Ibarra, Raul, \& Trupkin, Danilo R. (2016). Reexamining the relationship between inflation and growth: Do institutions matter in developing countries? Economic Modelling, Elsevier, 52(PB), 332-351.

12. Kartayev, Р. (2017). Влияние инфляционного таргетирования на динамику ВВП в долгосрочной перспективе: межстрановое исследование. Доклад на научном семинаре ЦМАКП [Vliyanie infliatsionnogo targetirovaniya na dinamiku VVP v dolgosrochnoi perspective: mezhstranovoye issledovaniye. Doklad na nauchnom seminare CMAKP]. Retrieved from http://www.forecast.ru/_ARCHIVE/Presentations/CMASF_SM/ mar2017/K-2017v5.pdf

13. Khan, M., \& Senhadji, A. (2001). Threshold Effects in the Relationship between Inflation and Growth. IMF Staff Papers, 48(1). Retrieved from http://www.imf.org/External/Pubs/ FT/staffp/2001/01a/pdf/khan.pdf

14. Kremer, S., Bick, A., \& Nautz, D. (2013). Inflation and growth: new evidence from a dynamic panel threshold analysis. Empirical Economics, Springer, 44(2), 861-878.

15. Kurihara, Y. (2013). Does Adoption of Inflation Targeting Reduce Exchange Rate Volatility and Enhance Economic Growth. Journal of World Economic Research, 2, 6, 104-109.

16. Leong, C.-M., Puah, C.-H., Liew, V., K.-S. (2018). The Impact of Divisia Money on Monetary Model of Exchange Rate in Indonesia. Economics and Sociology, 11(2), 52-63. Retrieved from http://www. economics-sociology.eu/?576,en the-impact-of-divisia-money-onmonetary-model-of-exchange-ratein-indonesia

17. Lin, S., \& Ye, H. (2007). Does inflation targeting really make a difference? Evaluating the treatment effect of inflation targeting in seven industrial countries. Journal of Monetary Economics, 54, 2521-2533.

18. Lioui, A., \& Poncet, P. (2008). Monetary Non-Neutrality in the Sidrauski Model under Uncertainty. Economic Letters, 100, 22-26.

19. López-Villavicencio, A., \& Mignon, V. (2011). On the impact of inflation on output growth: Does the level of inflation matter? Journal of Macroeconomics, 33, 455-464.

20. Malyovanyi, M., Nepochatenko, O., \& Nesterchuk, Y. (2018). Conceptual Approaches to Improving the Functioning of Non-state Social Insurance Institutions in Ukrai- ne. Economics and Sociology, 11(2), 289-304. Retrieved from https://economics-sociology.eu/ files/25_20_547_Malyovaniy\%20 et $\% 20 \mathrm{al} . . \mathrm{pdf}$

21. Mendoza, E. G., \& Terrones, M. E. (2008). An anatomy of credit booms: evidence from macro aggregates and micro data (NBER Working Paper 14049). Retrieved from http://www. nber.org/papers/w14049.pdf

22. Mishchenko, S. V., Naumenkova, S. V., \& Lon, I. M. (2016). Монетарні цикли в економіці України [Monetarni tsykly v ekonomitsi Ukrainy]. Aktualni Problemy Ekonomiky, 11, 363-372.

23. Mollick, A. V., Cabral, R., \& Carneiro, F. G. (2011). Does Inflation Targeting Matter for Output Growth? Evidence from Industrial and Emerging Economies. Journal of Policy Modeling, 33(4), 537-551.

24. Omay, T., \& Kan, E. O. (2010). Reexamining the Threshold Effects in the Inflation-Growth Nexus with Cross-Sectionally Dependent Nonlinear Panel: Evidence from Six Industrialized Economies. Economic Modelling, 27, 996-1005.

25. Orphanides, A., \& Solow, R. (1990). Money, Inflation and Growth. In B. M. Friedman \& F. H. Hahn (Eds.), Handbook of Monetary Economics. Amsterdam: North-Holland.

26. Pain, N., Koske, I., \& Sollie, M. (2006). Globalization and inflation in the OECD economies (OECD, Economic department Working Paper, 524).

27. Sachsida, A., Carneiro, F. G., \& Loureiro, P. R. A. (2003). Does Greater Trade Openness Reduce Inflation? Further Evidence using Panel Data Techniques. Economic Letters, 81, 315-319.

28. Sarel, M. (1996). Non-linear Effects of Inflation on Economic Growth. IMF Staff Papers 43(1), 199-215.

29. Zhuravka, F. O. (2008). Вплив девізної політики Національного банку України на обмінний курс гривні [Vplyv deviznoi polityky Natsionalnoho banku Ukrainy na obminnyi kurs hryvni]. Actualni Problemy Ekonomiky, 5, 54-160. 